УДК 547.97:664.8

DOI https://doi.org/10.37734/2518-7171-2021-1-2

\title{
ПЕРСПЕКТИВИ ОТРИМАННЯ АНТОЦАНОВИХ БАРВНИКІВ ДЛЯ ХАРЧОВОЇ ПРОМИСЛОВОСТІ
}

\author{
Т. М. ЛЕВКІВСЬКА, кандидат технічних наук, доцент \\ (Національний університет харчових технологій); \\ О. В. ДУЩАК, кандидат технічних наук \\ (Національний університет харчових технологій); \\ С. О. АБОВЯН \\ (Національний університет харчових технологій)
}

\begin{abstract}
Анотація. У статті розглянуто поняття «харчові добавки». Особливе місие серед харчових добавок посідають барвники, які використовуються у різних галузях харчової промисловості. Харчові барвники поділяють на натуральні, синтетичні та неорганічні. Нині спектр синтетичних барвників досить иирокий на противагу натуральним. Метою роботи було узагальнення науково-технічної інформацї щодо перспективної сировини для одержання натуральних харчових барвників - анточіанів, аналіз технологій ії перероблення.

Антоціани забарвлюють органи рослин у фіолетовий, синій, сизий, темно-червоний та рожевий кольори. Антоціани є сильними антиоксидантами - вони пов'язують вільні радикали кисню і перешкоджають пошкодженню мембран клітин.

Сировину, багату на антоціани, - ожину, чорницю, бузину, шовковицю, чорну смородину $і$ аронію - було досліджено за хімічним складом. Аналізуючи отримані дані, можна зробити висновок, щуо представлена сировина є джерелом не тільки барвних, а й біологічно активних речовин.

Оскільки розподіл антоціанів у плодах нерівномірний - у шкірочщзі їхній вміст у 3-7 разів вищий, ніжс у соку, бажано комплексно підійти до перероблення сировини. Так, можна отримати сік, який потім можна концеентрувати. Вичавки, які при цџьому утворилися, можна екстрагувати для вилучення барвних речовин; висушувати та отримувати порошок; розварювати і протирати з метою отримання пюре чи пасти. Таким чином можна отримати декілька продуктів, які б виконували роль барвника або біологічно активної добавки.

Однак під час розроблення технологї виробнищтва натуральних барвників слід пам'ятати, щзо забарвлення природних антоціанів залежить від рН середовища, утворення комплексів з металами, здатності адсорбуватися на полісахаридах, температури, світла.
\end{abstract}

Ключові слова: харчові добавки, натуральні барвники, антоціани, ожина, чорничя, бузина, иовковичя, чорна смородина, аронія.

Постановка проблеми у загальному вигляді. Харчові добавки використовуються людьми з давніх-давен. Однак лише наприкінці XIX століття почалося широке використання харчових добавок у сучасному розумінні і швидко досягло максимального поширення в усіх країнах світу.

Нині виробництво більшості харчових продуктів неможливе без застосування харчових добавок. Це пов'язано з удосконаленням технологій підготовки і перероблення харчової сировини, прискоренням або полегшенням технологічного процесу, транспортування і зберігання продуктів харчування, збереження природних якостей харчового продукту, збільшення стійкості продукту до різних видів псування, розроблення нових продуктів харчування та ін. Водночас використання харчових добавок і допоміжних засобів не повинне погіршувати органолептичні властивості продуктів. Не дозволяється також введення харчових добавок, здатних маскувати технологічні дефекти, псування початкової сировини і готового продукту або знижувати його харчову цінність (за винятком деяких продуктів спеціального і дієтичного призначення) [1].
Особливе місце серед харчових добавок посідають барвники. Натепер харчові барвники використовуються у виробництві численних харчових продуктів - кондитерських, макаронних, хлібобулочних та м'ясних виробів, алкогольних та безалкогольних напоїв, консервованих продуктів, маргаринів, спредів, снеків, йогуртів та ін. Метою їх застосування $\epsilon$ підвищення інтенсивності природного забарвлення або його відновлення після технологічного оброблення чи зберігання; покращення органолептичних властивостей; зафарбовування безбарвних продуктів [2;3].

Харчові барвники поділяють на натуральні (отримують фізичними способами 3 рослинної або тваринної сировини), синтетичні (органічні речовини, синтезовані хімічним способом, що не трапляються у природі) та неорганічні (отримують 3 мінеральної сировини природного походження). Також до речовин, що впливають на колір продукту, відносять фіксатори забарвлення та відбілювачі [1].

Нині спектр синтетичних барвників досить широкий. Перевагами їх застосування є дешевизна, малі дозування, стійкість до дії температури, 
світла, зміни $\mathrm{pH}$ середовища, отримання різноманітних відтінків шляхом змішування. Однак жоден 3 них не характеризується беззаперечною біологічною безпекою, і для таких харчових добавок встановлено максимально допустимий рівень у продукті.

Усі природні пігменти рослинного походження розподіляють на три групи: хлорофіли, каротиноїди та антоціани. Порівняно із синтетичними барвниками вони містять біологічно активні, можуть мати смакові та ароматичні речовини, що надають продуктам не тільки привабливого вигляду, але й природний аромат, смак і додаткову харчову цінність. Проте асортимент природних барвників, особливо вітчизняного виробництва, дуже малий.

Аналіз останніх досліджень і публікацій. Науковим дослідженням щодо пошуку сировини та розроблення технологій виробництва натуральних антоціанових барвників присвячені роботи багатьох учених.

Hock Eng Khoo, Azrina Azlan та ін. [4] займались вивченням натуральних та синтетичних антоціанових барвників, їхніх фізико-хімічних характеристик та впливу на організм. Запропоновано технології виробництва натурального барвника із виноградних шкірочок для виробництва джему фіолетового кольору, кондитерських виробів та напоїв.

B.M. Тимофеєвою проведені дослідження хімічного складу ягід аронії та бузини 3 можливістю використання їх для збагачення та зафарбовування харчових продуктів [5]. С.В. Матко, О.В. Бендерська, М.Г. Писарєв довели можливість використання як природних барвників концентрованих соків та паст з аронії, бузини, ожини та чорниці у виробництві кондитерських, хлібобулочних, макаронних виробів, молочних продуктів та харчоконцентратів [2; 6; 7].

B.I. Дейнекою та O.I. Шапошник досліджено антоціановий склад вишні, чорної смородини, винограду, жимолості та бузини. Науковцями також були проведені дослідження з вилучення барвних речовин із сировини шляхом екстрагування та сушіння 3 наступним використанням як природних барвників [8].

Науковцями (Г.П. Хомич, Л.А. Осипова, Л.В. Капрільянс, Н.І. Ткач, Г.М. Рибак) було доведено, що вміст антоціанів вищий у дикорослій сировині порівняно із культурними сортами. За пропонованою технологією 3 дикорослої сировини вилучали сік, а отримані вичавки направляли на екстрагування 3 метою вилучення фенольних речовин та антоціанів. Отримані екстракти було використано у виготовленні безалкогольних газованих напоїв, купажованих соків та компотів [9].

Формування цілей статті. Метою роботи $\epsilon$ узагальнення науково- технічної інформації щодо перспективної сировини для одержання натуральних харчових барвників - антоціанів, аналіз технологій ії перероблення.

Виклад основного матеріалу дослідження. Антоціани - рослинні глікозиди, що містять як аглікон (антоціанідин) гідрокси- та метокси заміщені солі флавілія (2-фенілхроменілія). Вуглеводна частина молекули (зазвичай залишок глюкози, рамнози, галактози, ди- або трисахарида) пов'язана $з$ агліконом у положенні 3 , рідше 3 та 5. Група антоціанів налічує близько 10 видів. Відомо вже понад 500 індивідуальних антоціанових сполук, та їхнє число постійно збільшується. Всі вони мають $\mathrm{C}_{15}$-вуглецевий скелет - два бензольні кільця А i В, з'єднані $\mathrm{C}_{3}$-фрагментом, який 3 атомом кисню утворює $\gamma$-піронове кільце (рисунок 1). При цьому від інших флавоноїдних сполук антоціани відрізняються наявністю позитивного заряду та подвійного зв’язку в С-кільці [10-13].

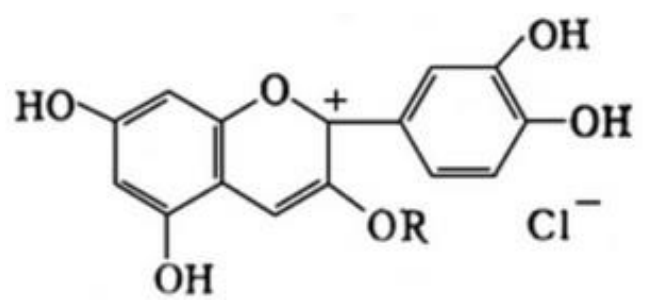

Рис. 1. Загальна структурна формула антоціанів

За всього їх великого різноманіття антоціанові сполуки - похідні лише шести основних антоціанідинів: пеларгонідину, пеонідину, дельфінідину, петунідину та мальвідину, які відрізняються бічними радикалами [11].

Антоціани накопичуються під час достигання фруктів, овочів і свідчать про ступінь їхньої стиглості. Саме вони забарвлюють у фіолетовий, синій, сизий, темно-червоний та рожевий кольори органи рослин. Різноманітність забарвлення антоціанів залежить від їхньої будови, від величини водневого показника клітинного соку - у кислому середовищі вони червоні, а в лужному - сині; а також залежить від характеру металу, що утворює комплекс $з$ антоціанами в рослині. Червоне забарвлення зумовлене утворенням комплексу із залізом; синє й фіолетове 3 молібденом, магнієм, кальцієм; біле - 3 нікелем або міддю; пурпурне - з калієм. Збільшення метильних груп у молекулі антоціанів змінює забарвлення у бік червоних відтінків $[1 ; 3 ; 10-13]$.

За біологічною ефективністю антоціани схожі на рутин. Так, антоціани здатні зміцнювати стінки капілярів і проявляти протинабрякову дію. У разі надходження 3 фруктами й овочами антоціани підтримують нормальний стан кров'яного тиску і судин, утворюючи комплекси з радіоактивними елементами, сприяють швидкому виведенню ї 3 організму. Крім того, ці пігменти здатні покращувати зір. Це дуже потужні антиоксиданти, що 
володіють більшою ефективністю, ніж аскорбінова кислота та токоферол. Антоціани проявляють бактерицидну дію, покращують когнітивні характеристики: пам'ять, координацію, просторову орієнтацію, здатність до навчання, моторні функції [3; 11].

У харчовій індустрії використовуються антоціанові барвники Е 163, отримані шляхом екстрагування зі шкірки червоного винограду, бузини, чорної смородини, шток-троянди, ожини, чорниці, вишні.

Найбагатшими на антоціани є ягоди, фрукти та овочі із синьою, фіолетовою, червоною шкіркою або м'якоттю, серед яких «рекордсменами» за вмістом цих речовин $є$ : ожина (320 мг/100 г), чорниця (560 мг/100 г), вишня (120 мг/100 г), журавлина $(150 \mathrm{мг} / 100$ г), шовковиця $(300 \mathrm{мг} / 100$ г), чорна смородина (280 мг/100 г), баклажани (750 мг/100 г)

Середній хімічний склад ягід

\begin{tabular}{|c|c|c|c|c|c|c|}
\hline \multirow[b]{2}{*}{ Показники } & \multicolumn{6}{|c|}{ Вміст } \\
\hline & Ожина & $\begin{array}{c}\text { Чорноплідна } \\
\text { горобина }\end{array}$ & Чорниця & Шовковиця & Бузина & $\begin{array}{c}\text { Чорна } \\
\text { смородина }\end{array}$ \\
\hline Вода, г & 88 & 81 & 84 & 87 & 80 & 82 \\
\hline Вуглеводи, г & 4,4 & 11 & 12 & 10 & 11 & 15 \\
\hline Харчові волокна, г & 2,9 & 4,1 & 2,4 & 1,7 & 7 & 4,8 \\
\hline Крохмаль та декстрини, г & - & 0,1 & 0,03 & 0,03 & - & - \\
\hline Моно- і дицукри, г & 4,4 & 10,8 & 10,0 & 8,1 & - & 7,3 \\
\hline Білки, г & 1,5 & 1,5 & 0,7 & 1,4 & 0,6 & 0,9 \\
\hline Жири, г & 0,5 & 0,2 & 0,3 & 0,4 & 0,5 & 0,4 \\
\hline Органічні кислоти, г & 2 & 1,3 & 2,0 & 1,2 & 0,3 & 3,0 \\
\hline Зола, г & 0,7 & 1,5 & 0,2 & 0,2 & 0,6 & 0,9 \\
\hline \multicolumn{7}{|c|}{ Вітаміни, мг } \\
\hline Ретинол & 0,017 & 0,2 & 0,003 & 0,0033 & 0,030 & 0,017 \\
\hline$\beta$-каротин & 0,1 & 1,2 & 0,032 & 9,0 & - & 100 \\
\hline Тіамін & 0,01 & 0,01 & 0,037 & 0,029 & 0,07 & 0,02 \\
\hline Рибофлавін & 0,05 & 0,02 & 0,041 & 0,02 & 0,06 & 0,024 \\
\hline Холін & 8,5 & 36 & 6 & 12,3 & - & 12,3 \\
\hline Пантонева кислота & 0,276 & 0,5 & 0,124 & 0,08 & 0,14 & 0,4 \\
\hline Піридоксин & 0,03 & 2 & 0,052 & 0,05 & 0,23 & 0,06 \\
\hline Фолати & 0,025 & 0,0017 & 0,006 & 0,006 & 0,006 & 0,005 \\
\hline Аскорбінова кислота & 15 & 15 & 9,7 & 36,4 & 36 & 113 \\
\hline Токоферол & 1,2 & 1,5 & 0,57 & 0,87 & - & 2 \\
\hline Біотин & - & 0,0025 & 0,0023 & 0,0006 & $\begin{array}{llll}- & \\
\end{array}$ & 0,0024 \\
\hline Філохінон & 0,0198 & 0,008 & 0,0193 & 0,0078 & 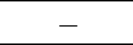 & 0,0001 \\
\hline Нікотинова кислота & 0,6 & 0,6 & 0,418 & 0,8 & 0,5 & 0,3 \\
\hline \multicolumn{7}{|c|}{ Макроелементи, мг } \\
\hline Калій & 208 & 158 & 77 & 194 & 280 & 244 \\
\hline Кальцій & 30 & 28 & 6 & 24 & 38 & 43,6 \\
\hline Кремній & - & 10 & 22 & 10 & - & 60,9 \\
\hline Магній & 29 & 14 & 6 & 18 & 5 & 19,4 \\
\hline Натрій & 21 & 4 & 1 & 10 & 6 & 2 \\
\hline Сірка & 0,0013 & 6 & 7,4 & 6 & 6,6 & 2 \\
\hline Фосфор & 32 & 55 & 12 & 38 & 39 & 31,7 \\
\hline \multicolumn{7}{|c|}{ Мікроелементи, мкг } \\
\hline Залізо & 1 & 1,1 & 0,28 & 1,9 & 1,6 & 0,51 \\
\hline Йод & - & 5 & 18,2 & 1 & - & 0,85 \\
\hline Кобальт & - & 15 & 0,9 & 1 & - & 4 \\
\hline Марганець & 0,646 & 0,5 & 0,336 & 18 & - & 47 \\
\hline Мідь & 165 & 58 & 57 & 60 & 6,1 & 77 \\
\hline Молібден & - & 8,7 & 2,4 & 0,6 & - & 24 \\
\hline Селен & 0,4 & 22,9 & 0,1 & 13,0 & 0,6 & 1,1 \\
\hline Фтор & - & 13 & 73,9 & 7 & - & 17 \\
\hline Цинк & 0,53 & 0,01 & 0,16 & 0,12 & 0,11 & 250 \\
\hline
\end{tabular}


та червоноголова капуста (150 мг/100 г), а також дикорослі ягоди: бузина (1200 мг/100 г), лохина (420 мг/100 г), аронія (1500 мг/100 г), лавровишня (500 мг/100 г). Також антоціани містяться в червоному апельсині, черешні, гранаті, солодкому перці, чорному рисі, червоній цибулі, шавлії, гороху, спаржі, бананах, груші, фенхелі, агрусі, томатах, глоді. При цьому в листі цих рослин концентрація антоціанів приблизно в десять разів вища, ніж у плодах або ягодах [5-9; 14; 15].

У таблиці 1 представлено середній хімічний склад ягід, багатих на антоціани.

Аналізуючи дані таблиці 1, можна зробити висновок, що представлена сировина є джерелом біологічно активних речовин. Продукти, отримані $з$ неї, можуть використовуватись не тільки для забарвлення, а ще й для збагачення харчових продуктів біологічно активними речовинами та підвищення їхніх антиоксидантних властивостей.

Як показують дослідження, розподіл антоціанів у плодах нерівномірний - у шкірочці їх вміст у 3-7 разів вищий, ніж у соку. Тому, застосувавши комплексний підхід до перероблення сировини, можна одержати декілька продуктів, які б виконували роль барвника або біологічно активної добавки. Так, можна отримати сік, який потім можна концентрувати. Вичавки, які при цьому утворилися, можна екстрагувати для вилучення барвних речовин; висушувати та отримувати порошок; розварювати і протирати з метою отримання пюре чи пасти $[8 ; 9 ; 14 ; 15]$.

$\mathrm{y}$ разі розроблення натуральних барвників необхідно пам'ятати, що забарвлення природних антоціанів залежить від будови, $\mathrm{pH}$ середовища, утворення комплексів з металами, здатності адсорбуватися на полісахаридах, температури, світла. Основним недоліком антоціанів $є$ зміна забарвлення барвника в результаті зміни $\mathrm{pH}$ середовища: за $\mathrm{pH} 1,5 \ldots 2$ - найбільш стійке червоне забарвлення; за $\mathrm{pH} 3,4 \ldots .5$ - червоно-пурпурове забарвлення (за рН вище 4,5 - як пігмент чорної смородини); за рН 6,7...8 - синє, синьо-зелене забарвлення; за рН 9 - зелене забарвлення; за підвищення $\mathrm{pH}$ до 10 - жовте забарвлення [11-13].

Висновки із зазначених проблем i перспективи подальших досліджень у поданому напрямі. На основі інформаційних джерел було 3'ясовано асортимент плодово-ягідної сировини з високим вмістом антоціанів. Використання такої сировини для виробництва натуральних харчових барвників $є$ актуальним натепер.

У разі комплексного підходу до перероблення ягід, багатих на антоціани, можна одержати не тільки барвники, а і смакові і біологічно активні добавки у вигляді пасти, порошку, екстрактів та концентрованих соків.

\section{СПИСОК ВИКОРИСТАНИХ ДЖЕРЕЛ}

1. Нечаев А.П., Кочеткова А.А., Зайцев А.Н. Пищевые добавки : учебник. Москва : Колос. 2001. 342 с.

2. Левківська Т.М., Матко С.В. Перспективи використання концентрованих соків як природних барвників. Новітні досягнення біотехнології : IV Міжнародна науково-практична конференція, яка присвячена 15-річчю кафедри біотехнології Національного авіаційного університету, 22-23 вересня 2020 р. Київ. 2020. С. 41-42.

3. Rajagopal P.L., Sreejith K.R., Premaletha K. Natural colorants as safe additives : A review : WWJMRD, 2016. No. 2(7). P. 28-32.

4. Khoo, Hock Eng \& Azlan, Azrina \& Tang, Sou \& Lim, See. Anthocyanidins and anthocyanins: Colored pigments as food, pharmaceutical ingredients, and the potential health benefits. Food \& Nutrition Research. 2017. No. 61. 1361779. DOI: $10.1080 / 16546628.2017 .1361779$.

5. Бурак Л.Ч, Тимофеева В.Н., Зенькова М.Л., Черепанова А.В. Исследование химического состава ягод бузины, произрастающей на территории Республики Беларусь. Вестник Могилевского государственного университета продовольствия. Могилев. 2012. № 1. С. 3-7.

6. Levkivska T., Benderska O., Pysarev M. Prospects of use of concentrated juice as food natural coloring. Theoretical foundations of modern science and practice : abstracts of XI International Scientific and Practical Conference. Melbourne, Australia, 2020. P. 106-108.

7. Левківська Т., Матко С., Романів В. Використання пасти аронії як наповнювача для харчових продуктів нового покоління. Оздоровчі харчові продукти та дієтичні добавки: технології, якість та безпека : матеріали Міжнародної науково-практичної конференції, 19-20 листопада 2020 р., Київ : НУХТ. 2020. С. 51-52.

8. Антоцианы плодов растений: опыт экстракции и сушки / В.И. Дейнека и др. Хранение и переработка сельхоз. сырья. Москва. 2006. № 4. С. 28-31.

9. Хомич Г.П., Ткач Н.І. Використання дикорослої сировини для забезпечення харчових продуктів БАР : монографія. Полтава : РВВ ПУСКУ. 2009. 159 с.

10. Tariq Pervaiz, Jiu Songtao, Faezeh Faghihi, Muhammad Salman Haider and Jinggui Fang. Naturally Occurring Anthocyanin, Structure, Functions and Biosynthetic Pathway in Fruit Plants. Journal of Plant Biochemistry \& Physiology. Barcelona, Spain. 2017. No. 5(2). Pp. 1-9.

11. Bąkowska-Barczak A. Acylated anthocyanins as stable, natural food colorants - A review. Pol J Food Nutr Sci. 2005. No. 14/55(2), pp. 107-116.

12. Laleh G.H., Frydoonfar H., Heidary R., et al. The effect of light, temperature, $\mathrm{pH}$ and species on stability of anthocyanin pigments in four Berberis species. Pak J Nutr. 2006. No. 5(1), pp. 90-21. 
13. Левківська Т.М., Абовян С.О. Антоціани рослинної сировини та їх вплив на організм людини. Виклики сьогодення та новації у харчових технологіях $і$ готельно-ресторанному бізнесі : матеріали науково-практичної конференції з міжнародною участю студентів, аспірантів та молодих вчених. 27 травня 2021 р., Київ: ККІБП. 2021. С. $72-74$.

14. Левківська Т.М. Перспективи використання чорниці для виготовлення натуральних барвників. Харчові технології та готельно-ресторанний бізнес: інновації і сучасні перспективи розвитку : матеріали ювілейної науково-практичної конференції з міжнародною участю студентів, аспірантів та молодих вчених. 29 квітня 2020 р. Київ : ККІБП. 2020. С. 78-79.

15. Горохова Я., Левківська Т. Отримання продуктів, багатих антоціанами, при комплексній переробці ожини. Наукові здобутки молоді - вирішенню проблем харчування людства у XXI столітті : матеріали 84-ї міжнародної наукової конференції молодих учених, аспірантів і студентів, 23-24 квітня. Київ : НУХТ. 2018. Ч. 1. С. 309.

\section{REFERENCES}

1. Nechaev, A.P., Kochetkova, A.A. \& Zaitsev, A.N. (2001). Pyshchevye dobavky: uchebnyk [Nutritional supplements]. Moscow: Kolos.

2. Levkivska, T.M., Matko, S.V. (2020). Perspektyvy vykorystannia kontsentrovanykh sokiv v yakosti pryrodnykh barvnykiv [Prospects for the use of concentrated juices as natural dyes]. Novitni dosiahnennia biotekhnolohii: IV Mizhnarodna naukovo-praktychna konferentsiia, yaka prysviachena 15-richchiu kafedry biotekhnolohii Natsionalnoho aviatsiinoho universytetu, (pp. 41-42). Kyiv [in Ukrainian].

3. Rajagopal, P.L., Sreejith, K.R., Premaletha, K. (2016). Natural colorants as safe additives: A review: WWJMRD (pp. 28-32), Delhi, India.

4. Khoo, Hock Eng \& Azlan, Azrina \& Tang, Sou \& Lim, See. (2017). Anthocyanidins and anthocyanins: Colored pigments as food, pharmaceutical ingredients, and the potential health benefits. Food \& Nutrition Research. 61. 1361779. DOI: $10.1080 / 16546628.2017 .1361779$.

5. Burak, L.Ch, Tymofeeva, V.N., Zenkova, M.L. \& Cherepanova, A.V. (2012). Yssledovanye khymycheskoho sostava yahod buzyny, proyzrastaiushchei na terrytoryy Respublyky Belarus [Study of the chemical composition of elderberries growing in the Republic of Belarus]. Vestnyk Mohylevskoho hosudarstvennoho unyversyteta prodovolstvyia, (pp. 3-7). Mohylev, Respublyky Belarus.

6. Levkivska, T., Benderska O. \& Pysarev M. (2020). Rrospects of use of concentrated juice as food natural coloring. Theoretical foundations of modern science and practice: abstracts of XI International Scientific and Practical Conference, (pp. 106-108). Melbourne, Australia.

7. Levkivska, T., Matko, S. \& Romaniv V. (2020). Vykorystannia pasty aronii yak napovniuvacha dlia kharchovykh produktiv novoho pokolinnia [The use of chokeberry paste as a filler for new generation foods]. Ozdorovchi kharchovi produkty ta diietychni dobavky: tekhnolohii, yakist ta bezpeka: materialy Mizhnarodnoi naukovo-praktychnoi konferentsii. (pp 51-52). Kyiv: NUKhT [in Ukrainian].

8. Deineka, V.Y. (2006). Antotsyany plodov rastenyi: opyt ekstraktsyy y sushky [Anthocyanins of plant fruits: experience of extraction and drying]. Khranenye y pererabotka selkhoz syria. Moscow: 4, $28-31$.

9. Khomych, H.P., Tkach, N.I. (2009). Vykorystannia dykorosloi syrovyny dlia zabezpechennia kharchovykh produktiv BAR [The use of wild raw materials to provide food]: monohrafiia. Poltava: RVV PUSKU [in Ukrainian].

10. Tariq Pervaiz, Jiu Songtao, Faezeh Faghihi, Muhammad Salman Haider and Jinggui Fang. (2017). Naturally Occurring Anthocyanin, Structure, Functions and Biosynthetic Pathway in Fruit Plants. Journal of Plant Biochemistry \& Physiology, (pp. 1-9). Barcelona, Spain.

11. Laleh, G.H., Frydoonfar H., Heidary R., et al. The effect of light, temperature, $\mathrm{pH}$ and species on stability of anthocyanin pigments in four Berberis species. Pak J Nutr. 2006, 5(1): 90-21.

12. Bąkowska-Barczak, A. Acylated anthocyanins as stable, natural food colorants - A review. Pol J Food Nutr Sci. 2005, 14/55(2): 107-116.

13. Levkivska, T.M., Abovian, S.O. (2021). Antotsiany roslynnoi syrovyny ta yikh vplyv na orhanizm liudyny [Anthocyanins of vegetable raw materials and their effect on the human body]. Vyklyky sohodennia ta novatsii $\mathrm{u}$ kharchovykh tekhnolohiiakh $\mathrm{i}$ hotelno-restorannomu biznesi: materialy naukovo-praktychnoi konferentsii $\mathrm{z}$ mizhnarodnoiu uchastiu studentiv, aspirantiv ta molodykh vchenykh (pp. 72-74). Kyiv: KKIBP [in Ukrainian].

14. Levkivska, T.M. (2020). Perspektyvy vykorystannia chornytsi dlia vyhotovlennia naturalnykh barvnykiv [Prospects for the use of blueberries for the manufacture of natural dyes]. Kharchovi tekhnolohii ta hotelnorestorannyi biznes: innovatsii y suchasni perspektyvy rozvytku: materialy yuvileinoi naukovo-praktychnoi konferentsii z mizhnarodnoiu uchastiu studentiv, aspirantiv ta molodykh vchenykh, (pp. 78-79). Kyiv: KKIBP [in Ukrainian].

15. Horokhova, Ya., Levkivska, T. (2018). Otrymannia produktiv, bahatykh antotsianamy, pry kompleksnii pererobtsi ozhyny [Obtaining products rich in anthocyanins in the complex processing of blackberries]. Naukovi zdobutky molodi - vyrishenniu problem kharchuvannia liudstva u XXI stolitti: materialy 84-yi mizhnarodnoi naukovoi konferentsii molodykh uchenykh, aspirantiv i studentiv, (p. 309). Kyiv: NUKhT [in Ukrainian]. 
T. Levkivska, PhD, Associate Professor (National University of Food Technology); O. Dushchak, PhD (National University of Food Technology); S. Abovian (National University of Food Technology). Prospects of obtaining antocyan colouring agents for the food industry.

Abstract. The concept of food additives is considered in the article. A special place among food additives belongs to colouring agents used in various branches of food industry. Colouring agents are divided into natural, synthetic and inorganic. Nowadays, the range of synthetic is quite wide against to natural ones. The aim of the work was to summarize scientific and technical information on potentially productive raw materials to get of natural food colouring agents - anthocyanins, analysis of technologies for (raw materials) processing.

Anthocyanins colour plant organs in violet, blue, dove-coloured, crimson, and pink. Anthocyanins are powerful antioxidants; they bind oxygen free radicals and prevent from damaging cell membranes.

The raw materials, rich in anthocyanins (blackberry, blueberry, elderberry, mulberry, black currant and chokeberry) were chemically studied. Analyzing the obtained data, we can conclude that the mentioned raw materials are not only the colouring agents but appear to be also a source of biologically active substances.

As distribution of anthocyanins in fruits is uneven the fruit peel contains, is by 3-7 times more than the juice, it is desirable to take a comprehensive approach to processing of the raw materials. So you can get the juice, to be concentrated later. The received pomace can be extracted: to get coloring substances; dry and obtain powder to; boil soft and cream, in order to obtain a puree or paste. Thus, you can get several products that would act as a dye or dietary supplement.

However, when developing natural colouring agents, one shall to remember that the color of natural anthocyanins depends on the structure, the pH of the environment, the formation of complexes with metals, the ability to adsorb on polysaccharides, depends on temperature and light.

Key words: food additives, natural colouring agents, anthocyanins, blackberry, blueberry, elderberry, mulberry, black currant, chokeberry. 